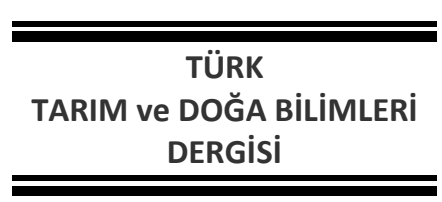

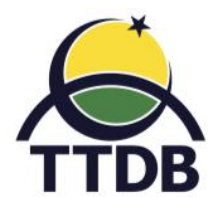

www.dergipark.gov.tr/turkjans

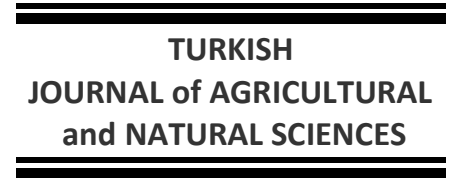

Araştırma Makalesi

\title{
TRA1 Bölgesinde (Erzurum, Erzincan, Bayburt) Hanelerin Kırmızı Et, Tavuk Eti ve Balık Eti Tüketimine Yönelik Mevcut Durum Üzerine Bir Araştırma
}

\author{
Nilgün DOĞAN*
}

Gümüşhane Üniversitesi Aydın Doğan MYO Kelkit Gümüşhane

*Sorumlu yazar: nilgun_stu@hotmail.com

\section{Özet}

Hayvansal protein kaynaklı gıdalar, gerek zihinsel gerekse bedensel gelişimde, dengeli beslenme için oldukça önem arz etmektedir. Gelişmiş ülkelerin beslenme desenlerinde hayvansal kaynaklı gıdalar ağırlıkta iken, FAO'ya göre Türkiye'de tahıl ve tahıl ürünleri en çok tüketilen gıda grupları içerisinde ilk sırada yer almaktadır. Türkiye'de kişi başına tüketilen 26 gr hayvansal proteinin \%35'i etten sağlanmaktadır. Bu tüketim düzeyi ile Türkiye, hayvansal kaynaklı tüketim bakımından dünya ile kıyaslandığında oldukça geride kalmaktadır. Hayvansal kaynaklı proteinlerin başında kırmızı et, tavuk eti ve özellikle sindirimi daha kolay, kalp hastalıklarının azalmasına yardımcı olan, omega-3 içeren balık eti gelmektedir. Bu araştırmada, TRA1 bölgesinde yer alan Erzurum, Erzincan ve Bayburt illerindeki hanelerin tüketim eğilimleri belirlenerek dengeli ve kaliteli beslenme açısından bölgenin mevcut durumu ortaya koyulmaya çalışılmıştır. Toplamda 400 hane ile yüzyüze görüşmeler yapılarak mevcut tüketim deseni hakkında bilgi toplanmıştır. Araştırma sonuçlarına göre; üç et çeşidini tüketenlerin oranı Erzincan'da \%70, Bayburt'ta \%63,8 ve Erzurum'da \%54,3 olarak elde edilmiştir. Tüketenlerin içeresinde en yüksek tavuk eti tüketim oranı (\%35) Erzurum'da iken bunu sırasıyla Erzincan $(\% 20,3)$ ve Bayburt $(\% 6,7)$ takip etmiştir. Kırmızı et ve balıketi tüketim oranları her üç ilde de birbirine yakın oranda bulunmuştur.

Anahtar kelimeler: Et çeşitleri, hane halkı, tüketim eğilimleri, TRA1 bölgesi.

\section{A Research on the Current Situation of the Red Meat, Chicken Meat and Fish Consumption Patterns in TRA1 Region (Erzurum, Erzincan, Bayburt Provinces)}

\begin{abstract}
Animal protein-based diet is very important for balanced nutrition, both mentally and physically. Nutrition patterns of the developed countries, while in the foods of animal origin according to the FAO cereals and cereal products in Turkey ranks first in the most consumed food groups. In Turkey, 26 grams consumed animal protein per capita is provided $35 \%$ of from the meat. With this amount Turkey is behind the world regarding animal protein consumption. Animal-derived proteins include red meat, chicken meat and fish that contains omega3, which are easier to digest and help reduce heart disease. In this research, the consumption trends of households in the region have been determined and the current situation of the region tried to be determined in terms of balanced and high quality nutrition. In total 400 households have been interviewed to collect the data in TRA1 region which consists of Erzurum, Erzincan and Bayburt provinces. The proportion of those consuming three types of meat was 70\% in Erzincan, $63.8 \%$ in Bayburt and $54.3 \%$ in Erzurum. The highest consumption of poultry (35\%) was followed by Erzincan (20.3\%) and Bayburt (6.7\%), respectively. Red meat and fish consumption rates were found in a similar ratio in all three provinces.
\end{abstract}

Key words: Meat types, household, consumption patterns, TR1A region. 


\section{Giriş}

Türkiye'de son yıllarda gıda tüketim kalıplarında önemli değişiklikler olmuştur (Üstün ve Tutal 2008; Demir ve Armağan 2013; Özer ve Akbay 2014; Nar 2015; Tekvar 2016; Terin ve ark., 2016; Bircan ve ark., 2017; Terin ve Bilgiç 2017; Gürler ve ark., 2018). Bu değişikliklerin başında; kentleşme, büyük şehirlere göç, kadınların işgücüne katılımı, sosyo-ekonomik ve demografik faktörlerdeki değişimler, teknolojideki gelişmeler, hazır gıda tüketim eğilimlerinin artması gibi sebepler gelmektedir. Bundan dolayı, tüketim deseninde gerçekleşen değişmelerin hanelerin gıda tüketim desenini ne derece etkilediğini ortaya koymak; ulusal anlamda gıda politikalarının oluşturulmasında, yatırımcıların uzun vadeli planlarında, iç pazarın şekillendirilmesinde ekonomik açıdan önem arz etmektedir. Uygun gıda politikalarını hazırlamak için, gıda tüketim desenini belirlemek oldukça önemlidir (Batalha ve ark., 2005). Beslenme alışkanlıkları ülkelerin gelişmişlik seviyelerini ortaya koyabilmektedir. Gelişmiş ülkelerin beslenme desenlerinde hayvansal kaynaklı gıdalar ağırlıkta iken, TÜik'e (2016) göre Türkiye'de tahıl ve tahıl ürünleri en çok tüketilen gıda grupları içerisinde ilk sırada yer almaktadır. Gerek zihinsel gerekse bedensel gelişimde önemli bir yere sahip olan günlük alınması gereken ortalama hayvansal protein miktarı dünya ile kıyaslandığında (50 gr), Türkiye ortalamanın altındadır. Türkiye hayvansal protein üretiminde, 36 gram ile 87 . ülke konumundadır. (FAO 2016). Türkiye'de hayvansal kaynaklı proteinlerin başında kırmızı et gelmekte ve kırmızı etin ana kaynağı kuzu eti ve dana etidir. Aşırı alımında kalp hastalıklarına sebep olan kırmızı et tüketimi uzmanlar tarafından haftalık $500 \mathrm{gr}$ ile sınırlandırılmakta iken, bunun yerine tavuk eti ve özellikle sindirimi daha kolay olan, kalp hastalıklarının azalmasına yardımcı olan, omega-3 içeren balık eti tüketilmesi tavsiye edilmektedir (Karabulut ve Yandı 2006; Turan ve ark., 2006; Erkan 2013; Turan ve ark., 2013). Yapılan araştırmalarda bütün kanser türlerinin \%30-40'ında yaşam tarzı ve beslenme alışkanlıklarının sorumlu olduğu tahmin edilmektedir. Aşırı kırmızı et ve et ürünlerinin tüketiminin ve omega-3 ve omega- 6 yağ asitlerinin dengesiz alımının kanser riskini artıran faktörler olabileceği belirtilmiştir (Çakmakçı ve Kahyaoğlu 2012). Türkiye'de, dengeli beslenmede önemli bir eksiklik olan hayvansal kaynaklı protein tüketiminin artırımasında kırmızı et, tavuk eti ve balık eti önemli rol oynamaktadır. Örneğin, Türkiye'de yıllık kişi başı tüketim ABD ile karşılaştırıldığında, hayvansal protein alımındaki düşük miktar dikkat çekmektedir. $A B D^{\prime}$ de yıllık kişi başı tüketilen kırmızı et miktarı 80,7 kg iken Türkiye'de ise 18,6 kg'dır (FAO 2015). Söz konusu miktarlarda şüphesiz ki, kırmızı et arzının payı büyüktür. Türkiye'de son yıllarda yerel et üretimini artırmaya yönelik çok ciddi yenilikler yapılmasına rağmen et ithalatının önüne geçilememiştir. Irkların ıslah edilememesi, yeterli ve ucuz miktarda yem bitkisi üretilememesi sonucu, 2007-2010 döneminde hayvan popülasyonunda önemli azalmalar olmuştur (Saygın ve Demirbaş 2017). Bununla birlikte, son yıllarda kırmızı ette yaşanılan problemler kanatlı et tüketimini olumlu yönde artırmıştır. Kişi başı kanatlı et tüketimi 2016 yılında 23 kg olmuştur (BESD-BíR 2016). Türkiye, üç tarafı denizlerle çevrili ve önemli su kaynaklarına sahip bir yarım ada ülkesi olmasına rağmen balık tüketimi ekonomik ve kültürel sebeplere bağlı olarak oldukça düşüktür. Türk Deniz Araştırma Vakfı raporuna göre; Türkiye'de kişi başı yıllık ortalama balık tüketim miktarı $7,6 \mathrm{~kg}$ olup dünya ortalamasının oldukça altındadır. Bölgelere göre tüketime baktığımızda Karadeniz bölgesinde kişi başı yıllık ortalama tüketim $25 \mathrm{~kg}$ iken İstanbul, Ankara ve İzmir'de 16 kg olup Doğu ve Güneydoğu Anadolu Bölgesinde ise sadece 0,5 kg'dır (TÜDAV 2018). Araştırma bölgesi kapsamında ki illerde, temel geçim kaynağı olarak hayvancılı̆ı̆n yaygın olarak yapılması beslenme şeklinde de kırmızı etin önemini artırmaktadır. Fakat hayvancılığın önündeki engeller, kırmızı etin aşırı alımında oluşan sağlık problemleri, yaşam standartlarının değişmesi, gelir gibi nedenlerden ötürü kırmızı etin yerini ağırlıklı olarak nispeten daha ucuz olan ve sağlık açısından önemli bir protein kaynağı olan tavuk ve balık eti alabilmektedir. Türkiye'de, il ve ilçe bazında kırmızı et, balık eti tüketimini etkileyen faktörler üzerine yapılan çalışmalar yaygındır (Yaylak ve ark., 2010; Hatırlı ve ark., 2007; Şahinli ve Fidan, 2012; Karakuş ve ark., 2008; Şen ve ark., 2008; Inci ve ark., 2014; Karlı ve Bilgiç, 2007).

Çalışmanın amacı, araştırma kapsamına alınan TRA1 bölgesinde (Erzurum, Erzincan, Bayburt) il merkezlerinde yaşayan hanelerin beslenme kalıplarında önemli bir yer tutan et çeşitlerinin tüketimini ve hanelerin bazı sosyoekonomik özellikleri ile et çeşitleri tüketim tercihleri arasındaki ilişkiyi belirlemektir. Bu araştırma, araştırma kapsamı ve ele alınacak değişkenler açısından ampirik literatürdeki eksikliği gidermeye çalışacaktır. Tüketim üzerinde ekonomik faktörler kadar etkili olan demografik faktörlerin etkisinin tüketim kararlarını nasıl etkilediği yatay kesit verileri kullanılarak ilk defa ortaya koyulacaktır.

Gıda tercihinde ve tüketim davranışlarında radikal değişiklikler birçok açıdan önem taşımaktadır (Kuhar ve Juvancic 2010). Bu noktada, gıda talep analizleri ile tüketim davranışlarına etki eden faktörlerin analizi; yatırım yapmak isteyen yatırımcıların uzun vadeli planlarında, iç pazarın şekillendirilmesinde, ülke ekonomisine yön verecek 
stratejilerin ve gıda politikalarının belirlenmesinde önemli rol oynamaktadır. Türkiye'de, hanelerin tüketim harcamalarında gıda harcamaları \%19,9'luk bir payla konut ve kira harcamalarından sonra ikinci sırada gelmektedir (Tüik 2016). Türkiye'de, özellikle Doğu ve Güneydoğu bölgelerinde beslenme kalıpları bakımından et ağırlıklı olarak beslenilmektedir. Son yıllarda yaşanılan değişmeler tüketicilerin beslenme alışkanlıklarını da etkilemektedir ve hayvansal ürünlere olan talebi zaman içinde değişebilmektedir. Bu durum tüketicinin kültür düzeyi, alım gücü, sosyal düzeyi ve gelişme süreci ile ilgilidir. Kültür düzeyi arttıkça karbonhidratlı gıdalar yerini proteinli gıdalar alabilmektedir (Cankurt ve ark., 2010). Bunun yanında, hayvansal ürünlere duyulan talebi bölgenin sosyo-ekonomik yapısı ve tüketim alışkanlıkları etkileyebilmektedir (Karakuş ve ark., 2008). Et tüketimini etkileyen bu faktörlerin yanında, ilçe bazında yapılan bir araştırmada hanede hasta olup olmamasının et talebini etkilediği ortaya konulmuştur (Yaylak ve ark., 2010). Başka bir tüketim çalışmasında ise ailede çalışan sayısının fazla olması, sabit ücretli olma ve eğitim değişkenlerinin kırmızı et tüketimini negatif fakat önemsiz seviyede etkilediği bulunmuştur (Karlı ve Bilgiç, 2007). Bedensel ve zihinsel gelişim için ve dengeli beslenmede büyük önem arz eden hayvansal kaynaklı proteinlerin tüketilmesinde kırmızı et, tavuk eti ve balık önemli protein kaynakları olarak bilinmektedir (Çolakoğlu ve ark., 2006; Hatırlı ve ark., 2007; Karlı ve Bilgiç 2007; Karakuş ve ark., 2008; Mutlu ve Yurdakul 2008; Şen ve ark., 2008; İnci ve ark., 2014; Karakaya ve İnci, 2014; Karakaya ve Kırıcı, 2016; Karakaya ve Kızıloğlu, 2017; Karakaya ve ark., 2018; Kırıcı ve ark., 2018). Kırmızı etin aşırı tüketiminde ortaya çıkabilecek kroner hastalıklar, kırmızı et fiyatlarındaki artış gibi nedenlerden dolayı tavuk eti tüketimi, hanelerin bütçelerinde önemli bir yer tutmaya başlamıştır. Yapılan bir araştırma, eğitim ve gelir değişkenlerinin tavuk eti tüketimini önemli derecede etkilediğini ortaya koymuştur (İnci ve ark., 2014).

Diğer taraftan, Türkiye'de kişi başı tüketimi oldukça düşük olan ve önemli bir protein kaynağı olan balık, ağırlıklı olarak kıyı şeridi illerinde tüketilmektedir. Dünya ortalamasının oldukça altında olan kişi başı $8 \mathrm{~kg} /$ yıllık tüketim, su ürünleri talep çalışmalarında dikkat çekmiştir (Dağtekin ve Ak 2007). Tarıma dayalı sanayinin gelişmesiyle raf ömrü uzayan, tüketilmesi daha pratik hale getirilen, her mevsim tüketilebilen, ürüne ulaşabilirlik gibi etkenlerle balık tüketimi, kıyı illerinin dışında olumlu yönde bir artış sağlamıştır. Yapılan bir araştırmada, balık tüketme eğiliminin yüksek olduğu ailelerde; annenin eğitim seviyesinin en az lise olduğu, bunun yanında ailenin aylık kırmızı et tüketim miktarının ise et fiyatını direkt etkilediği tespit edilmiştir (Şenol ve Saygı 2001). Bölgesel sosyo-demografik faktörlerin balık tüketimini etkilediğine dair yapılmış araştırmalardan birinde; tüketicilerin balık etini kırmızı ve tavuk etinden sonra üçüncü sırada tercih ettikleri, işlenmiş balık ürünleri tüketim alışkanlığının olmadığı, balık tüketimi konusunda orta düzeyde bilgiye sahip olunduğu bulunmuştur (Oğuzhan ve ark., 2009). Literatür araştırmalarından anlaşıldığı üzere; kırmızı et, tavuk eti ve balıketi konusunda yapılan araştırmaların çoğunluğu tüketim alışkanlıklarını ele alan ve tüketim desenini ortaya koyan il ve ilçe bazındadır. Kırmızı et, tavuk eti ve balık eti tüketimini etkileyen ekonomik faktörlerin yanında sosyo-ekonomik ve kültürel faktörlerinde etkili olduğu literatür taramasında anlaşılmıştır.

\section{Materyal ve Yöntem Veri}

Birincil veriler 2014 yılında hane kırmızı et, tavuk eti ve balık eti tüketim araştırması yoluyla toplanmıştır. Araştırma kapsamı olarak seçilen TRA1 bölgesinde ki iller Erzurum, Erzincan ve Bayburt'tur.

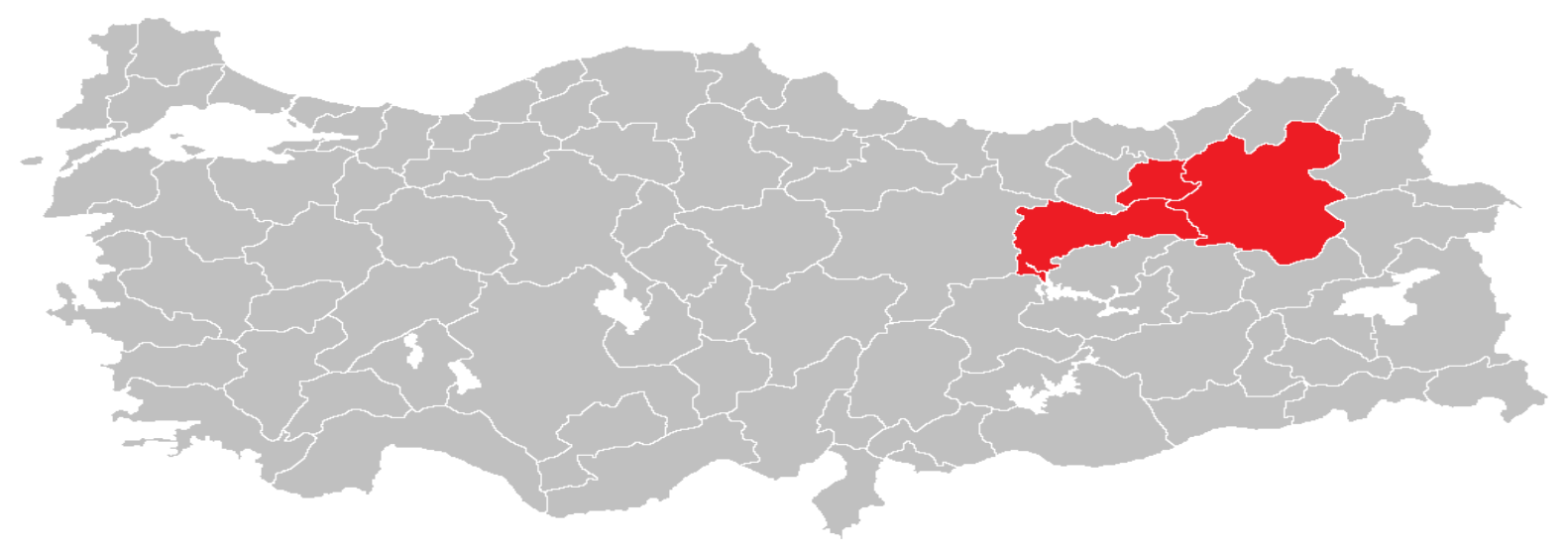

Şekil 1. Araştırma kapsamına alınan TRA1 bölgesi. 
Bu bölgenin seçilme nedeni; Erzurum Doğu Anadolu bölgesinde en yüksek nüfusa sahip illerden biri olup, temel geçim kaynağı olarak hayvancılığın yoğun olarak yapılmasıdır. Türkiye'de Tüik verilerine göre, 2017 yılında 16 milyon 105 bin büyükbaş, 44 milyon 312 bin de küçükbaş hayvan bulunmaktadır. Sığır sayısı en fazla olan ilk beş il içerisinde Erzurum yer almaktadır ve bu beş il Türkiye sığır varlığının \%21'ini oluşturmaktadır (TOB, 2018). Bu durum, Erzurum ilinin kırmızı et konusunda sahip olduğu potansiyelin göstergesidir. ilde, 457078 baş koyun olup, Doğu Anadolu Bölgesi'nde Van ve Iğdır'dan sonra 3. sırada, Türkiye'de ise 20. sırada yer almaktadır (TÜiK, 2016). Aynı zamanda, ilde tüm bölgeye dağıtım yapan Et Balık Kurumu bulunmaktadır. Balık yetiştiriciliğine bakıldığında, Erzurum ili zengin iç kaynaklara sahip olmasına rağmen, bu alanın yeterince değerlendirilemediği yapılan araştırmalarda mevcuttur (Aras ve ark., 2000; Kocaman ve ark., 2002; ZMO 2012). İlde, 503 ton su ürünü yetiştirilmektedir. Aynı bölgede bulunan Erzincan ve Bayburt illerinde kırmızı et, balık eti ve tavuk eti talebini ortaya koyacak herhangi bir araştırmaya rastlanılmamıştır. Bundan dolayı tüketim desenindeki değişmelerin bu illerdeki talebi nasıl etkilediğini ortaya koymak araştırmanın amacı açısından önem taşımaktadır. Hayvancılığın yoğun olarak yapıldığı TRA1 bölgesinde, verilere bakıldığında kırmızı et, tavuk eti ve balıketi tüketiminde ekonometrik modelin uygulamaya elverişli olduğu ve elde edilecek sonuçların bölgede tüketim kalıplarındaki değişmeyi yansıtacağı öngörülmektedir. Bu araştırmanın kapsamını Erzurum, Erzincan ve Bayburt illerinde yaşayan nüfus oluşturmuştur. Araştırma kapsamına alınan illerin 2013 yılındaki nüfusuna karşılık ana kitleyi oluşturan yaklaşık 1062345 hane halkı kapsama alınmıştır. Anket yapılacak tüketicilerin sayısı N araştırma kapsamına alınan toplam hane sayısı için; p üzerinde çalıştığımız özelliğin ana kitledeki oranıdır ve 0,50 alınmıştır ve ilgili et çeşitlerini tüketenlerin oranına göre örneklem büyüklüğü 400 olarak hesaplanmıştır. Araştırmada kullanılmış olan örnekleme yöntemi aşağıda verilmiştir (Newbold 1995). Örnek büyüklüğü \%95 güven aralığında ve 0,05 hata payı ile elde edilmiştir.

$$
n=\frac{\mathrm{Np}(1-\mathrm{p})}{(\mathrm{N}-1) \sigma^{2} p x+p(1-p)}
$$

Anket sonucu elde edilen veriler IBM SPSS V23 ile analiz edilmiştir. Verilerin normal dağılıma uygunluğu Shapiro Wilk ile incelenmiş ve normal dağılıma uymayan nicel verilerin illere göre karşılaştırılmasında Kruskal Wallis testi kullanılmıştır. Nitel verilerin tamamı ise Ki-kare testi ile incelenmiştir. Nicel veriler ortanca (min-mak) şeklinde sunulurken nitel veriler frekans (yüzde) olarak sunulmuştur. Önem düzeyi $p<0,05$ olarak alınmıştır. Anketler araştırma kapsamına alınan illerde kentsel kesimde yaşayan hanelerin ankete eşit olarak girme şansını sağlamak amacıyla; mahallerin sosyo-ekonomik özellikleri göz önünde bulundurulmuştur ve toplam örnek hacmi, üç ilin nüfusuna göre oransal olarak dağıtılmıştır. Anket için, mahallerde yaşayan hanelere tesadüfi olarak gidilmiştir. Anketler yüz yüze yapılmış ve öncelik, hanede alışverişi yapan tüketiciye verilmiştir. Anketlerin ilk bölümünü sosyo-ekonomik yapı, ikinci bölümünü ilgili ürünleri tüketim alışkanlıkları, üçüncü bölümü harcama gruplarına göre hane halkı aylık tüketim harcamasının dağıımı, dördüncü bölüm ise ilgili ürünlerin harcamalarını oluşturmaktadır.

\section{Bulgular ve Tartışma Tanımlayıcı istatistikler}

Hanehalkı ve hane reisine ait sosyodemografik özellikler Çizelge 1'de verilmiştir. Hanede görüşme yapılan kişiye ait medeni durum, çalışma durumu, yaş, cinsiyet, eğitim durumu, ailedeki birey sayısı, hanede kalp damar hastalığı olup olmama durumu, gelir gibi bilgiler sosyodemografik faktörleri oluşturmaktadır. Hanelerin tüketim desenini ortaya koyacak soruları ise; tercih edilen et çeşidi/çeşitleri, tüketim sıklığı, tercih edilen etin türü ve satın alma şekli oluşturmaktadır. Bununla birlikte hanelerin aylık ortalama tüketim harcamaları ve kırmızı et, tavuk eti ve balık eti aylık harcamaları da anketlerden elde edilmiştir. Araştırma kapsamına alınan illerdeki hanelerde görüşme yapılan katılımcıların büyük çoğunluğu kadındır (\%85,3). Hane reislerinin yaşlarına bakıldığında, \%5,8 lik gibi küçük bir kısmını 25 yaş altı oluştururken, \%61,8 lik gibi önemli bir kısmını $25-45$ yaş ve $\% 32,4$ lük kısmını ise 45 yaş ve üstü hane reisleri oluşturmuştur. Elde edilen verinin sağlıklı olması için anket yapılan hanelerde evde alışverişi yapan kişinin 18 yaş ve üstü olmasına dikkat edilmiştir. Eğitim değişkeni ele alındığında ise ilköğretim ve lise mezunu hane reislerinin ağırlıkta olduğu bulunmuştur. Hane reislerinin \%26,3'ü ilköğretim mezunu iken \%29,3'ü de lise mezunudur. Anket görüşmesine katılanların; yaklaşık $\% 65,9$ 'unun işi vardır ve hanelerin \%58,9'u 1000 TL ve $5000 \mathrm{TL}$ arası gelir grubundadır. Hanelerin \%32,1 'inin birey sayısı 4 ve üzeridir. Hanelerin $\% 83,3$ 'lük büyük bir kısmında kalp ve damar hastalıklarına rastlanılmamıştır. Et tüketim alışkanlıkları ile kalp ve damar hastalıkları arasında bir ilişki olup olmadığını görmek için ilgili faktör anket sorularına dâhil edilmiştir. 
Çizelge 1. Betimleyici istatistikler

\begin{tabular}{|c|c|c|c|c|}
\hline $\mathrm{n}(\%)$ & Erzurum $(n=300)$ & Bayburt $(n=30)$ & Erzincan $(n=70)$ & Toplam \\
\hline \multicolumn{5}{|l|}{ Cinsiyet } \\
\hline Erkek & $41(13.7)$ & $7(23.3)$ & $11(15.7)$ & $59(14.8)$ \\
\hline Kadın & $259(86.3)$ & $23(76.7)$ & $59(84.3)$ & $341(85.3)$ \\
\hline \multicolumn{5}{|l|}{ Aile reisinin yaşı } \\
\hline$<25$ yıl & $15(5)$ & $3(10)$ & $5(7.1)$ & $23(5.8)$ \\
\hline $25-45$ yıl & $187(62.8)$ & $17(56.7)$ & $42(60)$ & $246(61.8)$ \\
\hline$>45$ yıl & $96(32.2)$ & $10(33.3)$ & $23(32.9)$ & $129(32.4)$ \\
\hline \multicolumn{5}{|l|}{ Medeni durum } \\
\hline Evli & $45(15.1)$ & $6(20)$ & $11(15.7)$ & $62(15.6)$ \\
\hline Bekâr & $253(84.9)$ & $24(80)$ & $59(84.3)$ & $336(84.4)$ \\
\hline \multicolumn{5}{|l|}{ Çalışma durumu } \\
\hline Çalışıyor & $169(65.5)$ & $16(66.7)$ & $41(67.2)$ & $226(65.9)$ \\
\hline Çalışmıyor & $89(34.5)$ & $8(33.3)$ & $20(32.8)$ & $117(34.1)$ \\
\hline \multicolumn{5}{|l|}{ Ailenin aylık geliri } \\
\hline $600-1000 \mathrm{TL}$ & $104(34.7)$ & $4(13.3)$ & $10(14.5)$ & $118(29.6)$ \\
\hline $1001-3000 \mathrm{TL}$ & $95(31.7)$ & $11(36.7)$ & $36(52.2)$ & $142(35.6)$ \\
\hline $3001-5000 \mathrm{TL}$ & $65(21.7)$ & $10(33.3)$ & $18(26.1)$ & $93(23.3)$ \\
\hline 5001 ve üzeri & $36(12)$ & $5(16.7)$ & $5(7.2)$ & $46(11.5)$ \\
\hline \multicolumn{5}{|l|}{ Ailede birey sayısı } \\
\hline$<4$ & $208(69.6)$ & $15(50)$ & $48(68.6)$ & 271 (67.9) \\
\hline 4 ve üzeri & $91(30.4)$ & $15(50)$ & $22(31.4)$ & $128(32.1)$ \\
\hline \multicolumn{5}{|l|}{ Ailede kalp damar hastalığı } \\
\hline Yok & $245(81.7)$ & $26(86.7)$ & $62(88.6)$ & $333(83.3)$ \\
\hline Var & $55(18.3)$ & $4(13.3)$ & $8(11.4)$ & $67(16.8)$ \\
\hline \multicolumn{5}{|l|}{ Eğitim durumu } \\
\hline Okuryazar değil & $7(2.3)$ & $1(3.3)$ & $0(0)$ & $8(2)$ \\
\hline Okuryazar & $10(3.3)$ & $0(0)$ & $2(2.9)$ & $12(3)$ \\
\hline Ilköğretim & $89(29.8)$ & $3(10)$ & $13(18.6)$ & $105(26.3)$ \\
\hline Lise & $76(25.4)$ & $13(43.3)$ & $28(40)$ & $117(29.3)$ \\
\hline Önlisans & $22(7.4)$ & $5(16.7)$ & $2(2.9)$ & $29(7.3)$ \\
\hline Lisans & $61(20.4)$ & $7(23.3)$ & $17(24.3)$ & $85(21.3)$ \\
\hline Lisansüstü & $34(11.4)$ & $1(3.3)$ & $8(11.4)$ & $43(10.8)$ \\
\hline
\end{tabular}

\section{Araştırma kapsamına alınan illerde tercih edilen et çeşitleri ile ilgili bulgular}

Anket sonuçlarına göre tercih edilen et türleri illere göre farklılık göstermektedir $(p=0,007)$. Erzurum'daki hanelerin \%19,7'si balık eti, \%35'i tavuk eti, \%21,7'si kırmızı et ve \%54,3'ü de hepsini tükettiklerini belirtmişlerdir. Bayburt'ta \%23,3 balık eti, \%6,7 tavuk eti, \%26,7 kırmızı et ve \%70 her üç et türü tüketilmektedir. Erzincan'da yaşayan hanelerin \%13'ü balıketi, \%20,3'ü tavuk eti, \%24,6'sı kırmızı et ve $\% 63,8^{\prime} i$ de hepsini tüketmektedirler. Bayburt'ta tavuk eti tüketimi Erzurum'dan ve Erzincan'dan daha düşük elde edilmiştir. Bayburt'ta yaşayan hanelerin ağırlıklı olarak kırmızı et ve balık eti tükettiklerini ve anketlerin yapıldığı dönem, iç su balıklarının avlanma dönemlerine denk düştüğünden hanelerin belli bir kesiminin daha ekonomik olan iç su balıklarını tercih ettiğini bu sonuca istinaden söyleyebiliriz. Diğer et çeşitleri tüketim oranları arasında iller açısından fark olmadığı saptanmıştır. Her üç et çeşidini tüketenlerin oranı Bayburt ilinde diğer illere göre daha yüksek çıkmıştır (\%70). Erzincan'dan bir kişi tüketmiyorum cevabını vermiş ve bu kişi analiz dışı tutulmuştur (Çizelge 2). Karakaya ve İnci (2014) tarafından Bingöl'de yapılan benzer bir araştırmada, ankete katılanların büyük bir çoğunluğu (\%70) tavuk eti tüketirken \%30'unun kırmızı et tükettikleri belirlenmiştir. Dokuzlu ve ark.,'nın 2013 yılında Türkiye kapsamında bölgelere göre tavuk eti alışkanlıkları ile ilgili yapmış oldukları araştırmada Doğu Anadolu bölgesinde kent merkezlerinde yaşayan hanelerin kırsalda yaşayan hanelere göre tavuk eti tüketim miktarlarının daha düşük olduğu bulunmuştur. Araştırmamızın kapsamını oluşturan illerin bulunduğu Doğu Anadolu bölgesi için sadece Bayburt ilinde tercih edilen et çeşitleri arasında tavuk eti tüketim oranı $(\% 6,7)$ düşük çıkmıştır ve Erzurum, Erzincan illerinde tercih edilen tavuk eti kırmızı et oranları arasında çok büyük bir fark 
gözlemlenmemiştir. Erzurum ve Erzincan'da kırmızı et tüketim oranı sırasıyla $\% 21,7$ ve $\% 24,6$ iken tavuk eti tüketim oranı sırasıyla $\% 35$ ve $\% 20,3$ olarak elde edilmiştir.

Çizelge 2. illere göre tercih edilen et çeşitleri

\begin{tabular}{cccccc}
\hline Severek tüketilen et & Erzurum & Bayburt & Erzincan & Test istatistiği* & p \\
\hline Balıketi & $59(19.7) \mathrm{a}$ & $7(23.3) \mathrm{a}$ & $9(13.0) \mathrm{a}$ & & \\
Tavuk eti & $105(35.0) \mathrm{a}$ & $2(6.7) \mathrm{b}$ & $14(20.3) \mathrm{ab}$ & & \\
Kırmızı et & $65(21.7) \mathrm{a}$ & $8(26.7) \mathrm{a}$ & $17(24.6) \mathrm{a}$ & & 0.007 \\
Hepsi & $163(54.3) \mathrm{a}$ & $21(70) \mathrm{a}$ & $44(63.8) \mathrm{a}$ & & \\
\hline
\end{tabular}

*Ki kare test istatistiği, a-b: Her bir tüketilen et içerisinde aynı harfe sahip iller arasında fark yoktur.

\section{illere göre tüketilen et çeşitlerinin tercih nedenleri ile ilgili bulgular}

Kırmızı et tüketim nedenleri illere göre farklılık göstermektedir $(p=0,016)$. Erzurum, Erzincan ve Bayburt illerinde kırmızı et tüketme nedeni olarak ilk sırayı kırmızı etin lezzetli ve besleyici olması almıştır. Bu sonuçtan yola çıkarak kırmızı et tüketen hanelerin damak zevki ve sağlık etkenlerinin kırmızı et tercihinde önemli bir rol oynadığını belirtebiliriz. Diğer nedenler açısından bakıldığında iller arasında fark olmadığı saptanmıştır (Çizelge 3). Şeker ve Özen (2011)'nın Elazığ'da yapmış oldukları benzer çalışmada, katılımcıların yaklaşık \%50'si kırmızı eti lezzetli olmasından dolayı tükettiklerini ifade etmişlerdir. Tavuk eti tüketim nedenleri illere bağlıdır $(p<0,001)$. Bayburt'ta hanelerin \%78,3'ü lezzetli olması nedeniyle tavuk eti tükettiklerini belirtmişlerdir ve bu oran diğer illere göre en yüksektir. Bayburt ilinde aynı zamanda tavuk eti türünde ilk sırayı köy tavuğu aldığından lezzet faktörünün tercihte önemli bir rol oynadığı söylenebilir. Oysaki, Erzincan ve Erzurum'da tavuk eti tüketim nedeni oranı sırasıyla \%56,7 ve \%62,9 ile ucuz olması özelliği ilk sırada yer almaktadır. (Çizelge 3). Erzurum ve Erzincan illerindeki ankete katılan hanelerin tavuk etini tercih etme nedenlerinde ekonomik etkenlerin ağılıkta olabileceğini söyleyebiliriz. Balık eti tüketim nedenleri illere göre farklılık göstermektedir $(p=0,005)$. "Diğer" şeklinde neden belirtenlerin oranı Erzurum'da \%2,8 iken Erzincan'da \%9,1'dir ve aralarında fark vardır (Çizelge 3). Ertürk ve ark.,'nın (2014) Iğdır ilinde tavuk eti ve balık eti tercihlerini belirleyen araştırmalarında da benzer bulgulara rastlanılmıştır. Araştırmalarında, anket yapılan tüketicilerin büyük çoğunluğu lezzeti ve besleyici olması nedenlerinden tavuk eti tercih ettiklerini belirtirken, balıketi tercihinde ilk sırayı sağlıklı ve lezzetli olması almıştır. Uzundumlu ve ark.,'nın (2016) Hakkari ilinde yapmış oldukları balık eti ile ilgili çalışmada, balık eti tüketmek istemenin nedenleri sorulduğunda katılımcıların oldukça büyük bir kısmı $(\% 80,2)$ sağlıklı olması nedeni ile balıketi tükettiklerini belirtmişlerdir. Aynı sonuca, Abdikoğlu ve ark.,'nın (2015) yapmış olduğu çalışmada da rastlanılmıştır. Erdal ve Esengün
(2008) tarafından balıketi tüketimine yönelik yapılan bir çalışmada da hanelerin balığı tüketme nedenleri incelendiğinde, ilk sırada (\%87) sağlıklı olması faktörü belirlenmiştir. Hanelerin protein ağırlıklı hayvansal kaynaklı gıdalarla beslenmeleri, sağlıklı beslenme bağlamında tüketici bilincinin arttığına işaret olabilir. Çünkü, hanelerin sahip oldukları bilinç düzeyi tüketim eğilimlerini ve tüketim alışkanlarını belirleyecektir (Ersoy ve Sarıabdullahoğlu, 2010).

\section{illere göre et çeşitlerinin tüketim sıklığı bulguları}

Hanelerin et çeşitlerinin tüketim sıklıklarının illere göre dağılımı Çizelge 4'de sunulmuştur. Buna göre kırmızı etin tüketim sıklığı illere göre farklılık göstermemektedir $(p=0,084)$. Erzurum'da yaşayan hanelerin \%35,3'ü, Bayburt'ta yaşayan hanelerin \%40'ı ve Erzincan'da yaşayan hanelerin \%43,5'i haftada 1-3 kez kırmızı et tükettiklerini belirtmişlerdir. $\mathrm{Bu}$ oranlar ankette verilen diğer kırmızı et tüketim sıklıklarına göre daha yüksek çıkmıştır. Sonuç olarak, dengeli ve yeterli beslenmede önemli rol oynayan kırmızı etin araştırma kapsamına alınan hanelerde yeterli sıklıkta tüketildiğini söyleyebiliriz. Tavuk eti tüketimi illere göre farklılık göstermektedir $(p=0,001)$. Her üç ilde de ankete katılan hanelerin haftada 1-3 kez tavuk eti tüketim oranları diğer tüketim sıklıklarına göre daha yüksek olduğu saptanmıştır. Bayburt'ta haftada 1-3 kez tüketenlerin oranı \%69,6 iken Erzurum'da \%33,6 ve Erzincan'da \%37,7 olarak elde edilmiştir. Bayburt'taki hanelerin tavuk eti tüketim sıklığı diğer illerdeki orana göre en yüksektir (Çizelge 4). Balıketi tüketimi illere göre farklılık göstermektedir $(p<0,001)$. Erzurum ve Erzincan'da haftada 1-3 kez balık eti tüketenlerin oranı sırasıyla sadece $\% 12,2$ ve $\% 16,4$ iken, Bayburt'ta bu oran $\% 60,7$ 'dir. Bayburt'taki oran diğerlerine göre en yüksek çıkmıştır. Balık tüketimi ile ilgili elde edilen bu sonucun; anketlerin yapıldığı mevsim ile doğrudan ilişkisi olabileceği düşünülmektedir. Anketler, iç su balıkları avlanma döneminin yoğun olduğu döneme denk düşmüştür. Erzurum ve Bayburt yaşayan hanelerin ise, sırasıyla \%38'i ve \%36,4'ü ayda bir kez balık tükettiklerini belirtmişlerdir ve bu oranların ankette verilen diğer 
tüketim sıklıkları oranlarına göre en yüksek olduğu gözlemlenmiştir. Benzer sonucu Uzundumlu ve ark., (2016) tarafından Hakkari'de balıketi tüketim eğilimlerini etkileyen faktörlerin analizi üzerine yapılan araştırmada görebiliriz. Bu araştırmada, katılımcıların \%32'si ayda bir ve \%34'ü ise daha uzun sürede balıketi tükettiklerini ifade etmişlerdir.

Çizelge 3. Illere göre tüketilen et çeşitlerinin tercih nedenleri

\begin{tabular}{|c|c|c|c|c|c|}
\hline & Nedenler & Erzurum & Bayburt & Erzincan & $\mathbf{p}$ \\
\hline \multirow{7}{*}{ Kırmızı Et } & Lezzetli olma & $163(72.8)$ & $26(89.7)$ & $44(72.1)$ & \multirow{7}{*}{0.016} \\
\hline & Besleyici olma & $133(59.4)$ & $24(82.8)^{*}$ & $47(77)^{*}$ & \\
\hline & Alışkanlık & $66(29.5)$ & $13(44.8)$ & $25(41)$ & \\
\hline & Kolay bulunma & 29 (12.9) & $1(3.4)$ & $11(18)$ & \\
\hline & Ucuz olması & $2(0.9)$ & --- & --- & \\
\hline & Yağsız olması & $1(0.4)$ & --- & --- & \\
\hline & Diğer & $7(3.1)$ & --- & --- & \\
\hline \multirow{7}{*}{ Tavuk eti } & Lezzetli olma & $118(46.1)$ & $18(78.3)^{*}$ & 37 (61.7) & \multirow{7}{*}{$<0.001$} \\
\hline & Besleyici olma & 75 (29.3) & $10(43.5)$ & $27(45)$ & \\
\hline & Alışkanlık & $61(23.8)$ & $5(21.7)$ & $16(26.7)$ & \\
\hline & Kolay bulunma & $95(37.1)$ & $11(47.8)$ & $27(45)$ & \\
\hline & Ucuz olması & 161 (62.9)* & $6(26.1)$ & $34(56.7)^{*}$ & \\
\hline & Yağsız olması & $12(4.7)$ & --- & $5(8.3)$ & \\
\hline & Diğer & --- & --- & $1(1.7)$ & \\
\hline \multirow{7}{*}{ Balıketi } & Lezzetli olma & $94(44.1)$ & $19(67.9)$ & $33(60)$ & \multirow{7}{*}{0.005} \\
\hline & Besleyici olma & 109 (51.2) & 19 (67.9) & 37 (67.3) & \\
\hline & Alışkanlık & $22(10.3)$ & 5 (17.9) & $11(20)$ & \\
\hline & Kolay bulunma & $29(13.6)$ & $6(21.4)$ & $8(14.5)$ & \\
\hline & Ucuz olması & $86(40.4)$ & $7(25)$ & $16(29.1)$ & \\
\hline & Yağsız olması & $17(8)$ & $2(7.1)$ & $6(10.9)$ & \\
\hline & Diğer & $6(2.8)$ & --- & $5(9.1)^{*}$ & \\
\hline
\end{tabular}

Çizelge 4. İllere göre et çeşitlerinin tüketim sıklığı

\begin{tabular}{llccccc}
\hline & Sıklık & Erzurum & Bayburt & Erzincan & Toplam & p \\
\hline \multirow{6}{*}{ Kırmızı Et } & Her gün & $30(13.4)$ & $5(16.7)$ & $7(11.3)$ & $42(13.3)$ \\
& Haftada 1-3 & $79(35.3)$ & $12(40)$ & $27(43.5)$ & $118(37.3)$ \\
& Haftada 4-5 & $25(11.2)$ & $5(16.7)$ & $7(11.3)$ & $37(11.7)$ & 0.084 \\
& Ayda 1 defa & $57(25.4)$ & $6(20)$ & $7(11.3)$ & $70(22.2)$ & $40(12.7)$ \\
& Ayda 2-4 defa & $24(10.7)$ & $2(6.7)$ & $14(22.6)$ & $9(2.8)$ \\
& Yılda 1-3 kez & $9(4)$ & --- & --- & $9(2.6)$ \\
Tavuk eti & $6(2.3)$ & --- & $3(4.9)$ & $128(36.7)$ \\
& Her gün & $89(33.6) \mathrm{b}$ & $16(69.6) \mathrm{a}$ & $23(37.7) \mathrm{b}$ & $49(14)$ \\
& Haftada 1-3 & $30(11.3)$ & $4(17.4)$ & $15(24.6)$ & $\mathbf{0 . 0 0 1}$ \\
& Haftada 4-5 & $63(23.8)$ & $3(13)$ & $10(16.4)$ & $76(21.8)$ \\
& Ayda 1 defa & $76(28.7) \mathrm{a}$ & --- & $9(14.8) \mathrm{b}$ & $85(24.4)$ \\
& Yılda 2-4 defa & $1(0.4)$ & --- & $1(1.6)$ & $2(0.6)$ \\
Balıketi kez & $1(0.5)$ & $1(3.6)$ & $1(1.8)$ & $3(1)$ \\
& Her gün & $25(12.2) \mathrm{a}$ & $17(60.7) \mathrm{b}$ & $9(16.4) \mathrm{a}$ & $51(17.7)$ \\
& Haftada 1-3 & $7(3.4)$ & $2(7.1)$ & $3(5.5)$ & $12(4.2)$ \\
& Haftada 4-5 & $78(38)$ & $7(25)$ & $20(36.4)$ & $105(36.5)$ \\
& Ayda 1 defa & $73(35.6)$ & --- & $17(30.9)$ & $90(31.3)$ \\
& Ayda 2-4 defa & $18(8.8)$ & $1(3.6)$ & $4(7.3)$ & $23(8)$ \\
& Yılda 1-3 kez & & & &
\end{tabular}

illere göre tüketilen et türleri ile ilgili bulgular Kırmızı et tüketiminde hangi tür etin tüketildiği illere göre farklılık göstermemektedir $(p=0,179)$. Erzurum'da \%75,2 oranında, Erzincan'da $\% 77,8$ ve Bayburt'ta $\% 65,5$ oranında sığır eti tüketilmektedir. Araştırma kapsamına alınan illerdeki hanelerin kırmızı et kaynağının ağırlıklı olarak sığır eti olduğu belirlenmiştir. Karakuş ve ark., (2008) tarafından yapılan bir çalışmada ise, en çok tercih edilen kırmızı et türünün koyun $(\% 77,9)$ 
olduğunu bulmuşlardır. Tavuk eti tüketimleri illere göre farklılık göstermektedir ( $p=0,003)$. Köy tavuğu tüketimi Bayburt'ta \%50, Erzurum'da \%21,5 ve Erzincan'da \%24,6'dır. Bayburt'ta bu oran diğerlerinden daha yüksektir. Bu bulgulara göre; Bayburt'ta yaşayan haneler diğer illerde yaşayan hanelere göre daha fazla köy tavuğu tercih etmektedirler. Bu tercihin nedenleri arasında, köy pazarlarında köy tavuğu satın almanın kolaylığı, lezzeti, satın alma alışkanlıkları ve damak tadının geldiği araştırmanın bulguları tarafından desteklenmektedir. Fakat araştırmada fabrika tavuk eti tüketen hanelerin her üç il için diğer tavuk eti türlerine göre yüksek oranda olduğu tespit edilmiştir. Erzurum ilinde fabrika tavuğu tüketenlerin oranı $\% 83,6$ iken bunu sırasıyla Erzincan \%71,3 ve Bayburt \%66,7 oranla takip etmektedir. Fabrika tavuk etinin yaygın pazarı, kolay ulaşılması ve fiyatının ucuzluğu nedeniyle daha fazla tercih edildiği anlaşılmaktadır. Olgunoğlu ve ark. (2014) tarafından Adıyaman'da yapılan bir çalışmada, tavuk eti tüketimi, (\%56) kırmızı et (\%38) ve balık etine (\%5) göre daha yüksek çıkmıştır. Çalışmada, balık tüketen hanelerin \%70'i tatlı su balıklarını ve \%30'u deniz balıklarını tükettiklerini bildirmişlerdir. Balıketi türü illere göre farklılık göstermektedir $(p=0,001)$. Ilginç bir şekilde, çipura tüketimi en yüksek Erzincan'da $(\% 25,5)$ elde edilmiştir ve söz konusu illerde alabalık, hamsi ve istavrit türlerinin ağırlıklı olarak tüketildiği Çizelge 5'de görülmektedir. Her üç ilde de hamsi tüketim oranı diğer illere göre daha yüksek çıkmıştır. Erzurum'da ankete katılan hanelerin yaklaşık \%34'ü alabalık tüketirken bu oranın Bayburt ve Erzincan'da daha yüksek olduğu görülmüştür (\%44,4, \%45,5). Bu sonuç, ilgili bölgede hanelerin balık türlerinden hamsiyi tercih ettiklerini göstermektedir. Bununla birlikte tatlı su balığı olan alabalık tüketim oranının yüksekliği de dikkat çekmektedir. Kıyılarda yaşayan hanelere göre tüketim oranı daha düşük olması beklenilen balık etinin iç su balıkları nedeniyle beklenilenden daha fazla tüketildiği anlaşılmıştır.

Çizelge 5. Illlere göre tüketilen et türleri

\begin{tabular}{llccccc}
\hline & Et türü & Erzurum & Bayburt & Erzincan & Toplam & $\mathbf{p}$ \\
\hline \multirow{5}{*}{ Kırmızı Et } & $173(75.2)$ & $19(65.5)$ & $49(77.8)$ & $241(63.1)$ & \\
& Sığır & $39(17)$ & $8(27.6)$ & $17(27)$ & $64(16.8)$ & 0.179 \\
& Koyun & $3(1.3)$ & $1(3.4)$ & $4(6.3)$ & $8(2.1)$ & \\
& Keçi & $49(21.3)$ & $7(24.1)$ & $13(20.6)$ & $69(18.1)$ & \\
& Hepsi & $31(11.3)$ & $2(8.3)$ & $2(3.3)$ & $35(8.3)$ & 0.003 \\
Tavuk Eti & Organik & $59(21.5) \mathrm{a}$ & $12(50) \mathrm{b}$ & $15(24.6) \mathrm{a}$ & $86(20.4)$ & \\
& Köy tavuğu & $230(83.6)$ & $16(66.7)$ & $54(88.5)$ & $300(71.3)$ & \\
& Fabrika & $26(11.8) \mathrm{a}$ & $4(14.8) \mathrm{ab}$ & $14(25.5) \mathrm{b}$ & $44(8.8)$ & \\
& Çipura & $21(9.5)$ & $3(11.1)$ & $9(16.4)$ & $33(6.6)$ & \\
& Levrek & $33(14.9)$ & $6(22.2)$ & $14(25.5)$ & $53(10.6)$ & \\
& İstavrit & $75(33.9)$ & $12(44.4)$ & $25(45.5)$ & $112(22.5)$ & 0.001 \\
& Alabalık & $114(51.6)$ & $16(59.3)$ & $38(69.1)$ & $168(33.7)$ & \\
& Hamsi & $71(32.1) \mathrm{a}$ & $7(25.9) \mathrm{ab}$ & $8(14.5) \mathrm{b}$ & $86(17.3)$ & \\
& Farketmez & $0(0)$ & $0(0)$ & $2(3.6)$ & $2(0.4)$ \\
\hline
\end{tabular}

\section{Sonuç ve Öneriler}

Günlük alınması gereken protein miktarının önemli bir kısmını oluşturan hayvansal protein kaynağı olan kırmızı et, tavuk eti ve balık etinin tüketim miktarı ve tercihlerini ortaya koymak için TRA1 bölgesinde yer alan illerde hanehalkı verilerine dayalı olarak yapılan bu araştırmadan aşağıdaki sonuçlar elde edilmiştir.

Araştırmadan elde edilen sonuçlara göre, her üç et çeşidini severek tüketen hanelerin oranı Erzurum, Bayburt ve Erzincan'da sırasıyla \%54,3, $\% 70$ ve $\% 63,8$ olarak elde edilmiştir. Bu sonuca istinaden, özellikle Bayburt ve Erzincan'da yaşayan hanelerin beslenme desenlerinde tercihlerinin ağırlıklı olarak hayvansal kaynaklı besinler olduğunu söyleyebiliriz. Kırmızı et tüketim oranları her üç ilde de birbirine yakın iken Erzurum ilinde tavuk eti \%35 lik bir oranla en yüksek, Bayburt ilinde ise $\% 6,7$ lik oranla en düşük tercih edilen et çeşidi olarak elde edilmiştir. Söz konusu illerin kıyısı olmamasına rağmen balık eti tüketim tercih oranı, Bayburt ve Erzurum illerinde ankete katılan hanelerde (sırasıyla yaklaşık \%20 ve \%23,3) Erzincan iline $(\% 13,3)$ göre daha yüksek elde edilmiştir. Kırmızı et tercih nedeni olarak lezzet ve besleyici olma özellikleri ankette belirtilen diğer özelliklere göre her üç ilde de yüksek oranda elde edilmiştir. Doğu mutfağında ağırlıklı olarak yer alan kırmızı et, nesillerdir bir yemek kültürü olarak yerini almaya devam ettiğini söyleyebiliriz. Erzurum ve Erzincan illerinde ankete katılan hanelerin tavuk eti tüketim tercih nedenlerinin ilk sırasında ucuz olması gelirken Bayburt'ta ise lezzet faktörü \%78,3 oranla ilk sırada yerini almıştır. Bayburt'ta yaşayan hanelerin tavuk 
eti türünde ağırlıklı olarak köy tavuğunu tüketmesinin bu sonucu etkilediği söylenebilir. Araştırma kapsamına alınan hanelerde balık eti tüketiminde ise aynı tablo ile karşılaşılmıştır. Her üç ilde de balık tüketim oranında ilk sırayı lezzetli olma alırken bunu sırasıyla besleyici ve daha ucuz olması nedenleri takip etmiştir. Haliyle, daha ucuz ve ikamesi yüksek olan tavuk eti ve balık eti, hanelerin tüketim deseninde önemli bir yer tuttuğu araştırmanın bulgularıyla desteklenmektedir. Haneler balık türü olarak ilk sırada daha ucuz elde edebilecekleri tatlı su balıklarını ve deniz balıklarından hamsi ve istavriti ağırlıklı olarak tercih etmişlerdir. Kırmızı et, tavuk eti ve balık eti üretiminin temel girdisi olan yem, üretimde maliyetin büyük bir bölümünü oluşturmaktadır. Yemin temel girdilerinin önemli bir kısmı ithal edilmekte ve genel anlamda dışa bağımlılık söz konusudur. Bu nedenle tüketimin artırılmasında üretimde sağlanabilecek sürdürebilirlik, stratejik bir önem taşımaktadır. Türkiye'de tarım alanındaki kooperatiflerin üretici lehinde etkin çalışamadıkları bir gerçektir. Kooperatiflerin etkin çalışması et üretiminin arzına yönelik olumsuzlukları bertaraf etmede önemli olabileceği ve bunun neticesinde tüketimin artması beklenilen çıktılar arasında yerini alacaktır. Bu araştırma, söz konusu illerde hanelerin mevcut tüketim desenini ortaya koymak için yapılmıştır. Araştırma bölgesinde yer alan söz konusu illerde beklenilenin aksine tavuk eti ve balık etinin kırmızı etin yerine ikame özelliğinin yüksek olduğu araştırmanın sonuçları arasındadır. Bu nedenle özellikle deniz balıkları tüketimi için gerekli çalışmaların yapılması, ilgili hanelerin tüketim deseninde balık tüketiminin daha fazla yer almasına yardımcı olacağı düşünülmektedir. Bir sonra ki araştırma bu veriden yola çıkarak hanelerin ilgili et tüketimlerini etkileyen faktörlerin ekonometrik analizinin yapılması olacaktır. Özellikle pazarlama alanında yapılacak çalışmalar için, bu araştırma TRA1 bölgesinde bulunan hanelerin tüketim desenini ortaya koymada kısmen de olsa veri sağlayabilecektir.

\section{Kaynaklar}

Abdikoğlu, D.i.., Azabağaoğlu, Ö., Unakıtan, G. 2015. Tekirdağ ilinde balık tüketim eğilimlerinin belirlenmesi. Balkan ve Near Eastern Journal of Social Sciences, 01(01): 69-75.

Aras, N.M.., Yanık, T., Kocaman, M.S. 2000. Kuzeydoğu Anadolu bölgesi su ve su ürünleri potansiyelinin değerlendirilmesi. Atatürk Üniv. Ziraat Fak. Derg., 31(Özel Sayı): 125130.

Batalha, M.O., Lucchese, T., Lambert, J.L. 2005. Hábitos de consumo alimentar no Brasil: realidade e perspectivas. In: Batalha, Mario
O. (Coord.). Gestão do Agronegócio - Textos selecionados. São Carlos: Edufscar.

Beyaz Et Sanayicileri ve Damızlıkçıları Birliği (BESDBiR) 2015 Kayıtları, 2015. http://www.besdbir.org/assets/documents/secilmiA_ylkeler_ tyketim1 (Erişim tarihi: 20.03.2016).

Bircan, H., Eleroğlu, H., Arslan, R. 2017. Sivas kent merkezinde tavukçuluk ürünlerinin tüketimi ve tüketime etki eden faktörler. Türk Tarım Gıda ve Teknoloji Dergisi, 5(12): 1609-1614.

Cankurt, M., Miran, B., Şahin, A. 2010. Sığır eti tercihlerini etkileyen faktörlerin belirlenmesi üzerine bir araştırma: İzmir ili örneği. Hayvansal Üretim, 51(2):16-22.

Çakmakçı, S., Kahyaoğlu, D. 2012. Yağ asitlerinin sağlık ve beslenme üzerine etkilerine genel bir bakış. Akademik Gıda, 10(1): 103-113.

Çolakoğlu, F.A., İşmen, A., Özen, Ö., Çakır, F., Yığın, Ç., Ormancı, H.B. 2006. Çanakkale ilindeki su ürünleri tüketim davranışlarının değerlendirilmesi. E.Ü. Su Ürünleri Dergisi, 23(1/3):387-392.

Dağtekin, M., Ak, O., 2007. Doğu Karadeniz bölgesinde su ürünleri tüketimi, ihracat ve ithalat potansiyeli. SUMAE Yunus Araştırma Bülteni, 7(3): 14-17.

Demir, Y., Armağan, G. 2013. Aydın'da hanehalklarının gıda tüketim talebi ekonometrik analizi. Ege Üniversitesi Ziraat Fak. Dergisi, 50(1): 97-107.

Dokuzlu, S., Barış, O., Hecer, C., Güldaş, M. 2013. Türkiye'de Tavuk eti tüketim alışkanlıkları ve marka tercihleri. Uludağ Üniversitesi Ziraat Fakültesi Dergisi, 27(2): 83-92.

Erdal, G., Esengün, K. 2008. Tokat ilinde balık tüketimini etkileyen faktörlerin logit model ile analizi. Ege Üniversitesi Su Ürünleri Dergisi, 25(3): 203-209.

Erkan, N. 2013. Türkiye'de tüketilen su ürünlerinin omega-3 yağ asidi profilinin değerlendirilmesi. Journal of Fisheries Sciences, 7(2): 194-208.

Ersoy, A.F., Sarıabdullahoğlu, A. 2010. Erken dönemde tüketici bilincinin geliştirilmesi. Üçüncü Sektör Kooperatifçilik, 45(1): 65-76.

Ertürk, E., Karadaş, K., Şahin, K. 2014. Iğdır ilinde tüketicilerin tavuk eti ve balık tercihlerini belirleyen faktörler. XI. Ulusal Tarım Ekonomisi Kongresi, 3-5 Eylül, Samsun, s. 1356-1364.

Food Agriculture Organisation (FAO) Kayıtları (2015), Kırmızı et tüketimi. http://www.fao.org/3/y4252e/y4252e05b.h tm (Erişim tarihi: 20.03.2016).

Food Agriculture Organisation (FAO) protein tüketimi. 
http://www.fao.org/3/t0562e/T0562E05.ht m (Erişim tarihi: 20.03.2016).

Gürler, Ö., Birecikli, Ş., Eryavuz, A. 2018. Türkiye'de hanehalkı tüketim ve gıda harcamalarının Kantil regresyon yöntemiyle araştırılması. International Journal of Economic and Administrative Studies, 18(Özel Sayı): 219238.

Hatırlı, A., Öztürk, E., Aktaş, A.R. 2007. Kırmızı, tavuk ve beyaz et talebinin tam talep sistemi yaklaşımıyla analizi. Süleyman Demirel Üniversitesi Sosyal Bilimler Enstitüsü Dergisi, 2(6): 212-220.

İnci, H., Karakaya, E., Şengül, T., Söğüt, B. 2014. Bingöl ilinde kanatlı eti tüketiminin yapısı. Türk Tarım ve Doğa Bilimleri Dergisi, 1: 1824.

Karabulut, H., Yandı, ì. 2006. Su ürünlerindeki omega-3 yağ asitlerinin önemi ve sağlık üzerine etkisi. E.Ü. Su Ürünleri Dergisi, 1(3):339-342.

Karakaya, E., İnci, H. 2014. Bingöl ili merkez ilçesi hane halkının kanatlı eti tüketim tercihleri. Uludağ Üniversitesi Ziraat Fakültesi Dergisi, 28(1): 53-64.

Karakaya, E., Kırıcı, M. 2016. Bingöl İli Kent Merkezinde Balık Eti Tüketim Alışkanlıklarının Belirlenmesi. Uluslararası Sosyal ve Ekonomik Bilimler Dergisi. 6(1): 7485.

Karakaya, E., Kızıloğlu, S. 2017. Analysis of factors affecting red meat demand of households living in Bingol city center. Anadolu Tarım Bilimleri Dergisi, 32(2): 169-180.

Karakaya, E., Çelik, Ş., Taysı, M.R. 2018. CHAID Algoritması ile Balık Eti Tüketimini Etkileyen Faktörlerin İncelenmesi. Gaziosmanpaşa Üniversitesi Ziraat Fakültesi Dergisi. 35(2): 85-93.

Karakuş, K., Aygün, T., Alarslan, E. 2008. Gaziantep ili merkez ilçede kırmızı et tüketim alışkanlıkları. Yüzüncü Yıl Üniv. Tarım Bilimleri Dergisi, 18(2): 113-120.

Karlı, B., Bilgiç, A. 2007. Factors affecting meat and meat products consumption quantities in Şanlıurfa province. Akdeniz Üniversitesi Ziraat Fakültesi Dergisi, 20(1): 127-136.

Kırıcı, M., Çam, O., Karakaya, E. 2018. Siirt ili kent merkezinde balık eti tüketim yapısı ve tüketicilerin satın alma eğilimlerinin belirlenmesi. Akademik Ziraat Dergisi 7(2):227-236

Kocaman, E.M., Aydın, A., Özer, A. 2002. Erzurum'da faaliyet gösteren alabalık işletmelerinin yapısal ve ekonomik analizi. E.Ü. Su Ürünleri Dergisi, 19(3-4): 319-327.
Kuhar, A., Juvancic, L. 2010. What Determines Purchasing Behaviour for organic and integrated fruits and vegetables?. Bulgarian Journal of Agricultural Science. 16 (No 2):111-122.

Mutlu, S. ve Yurdakul, O., 2008. Gıda güvenirliği açısından tüketici davranışları (Adana kentsel kesimde kırmızı et tüketimi örneği). Çukurova Fen Bilimleri Enstitüsü, 17(4), 4959.

Nar, M.Ş. 2015. Küreselleşmenin tüketim kültürü üzerindeki etkisi: teknoloji tüketimi. Uluslararası Sosyal Araştırmalar Dergisi, 8(37): 941-952.

Newbold, P., 1995. Statistic for Business and Economics. Prentice-Hall, New Jersey.

Oğuzhan, P., Angiş, S., Atamanalp, M. (2009). A research on the habits fish products consumption of consumers determination in Erzurum (in Turkish with English abstract). XV. National Fisheries Symposium, 01-04 July 2009, Rize: 01-04.

Olgunoğlu, İ., Bayhan, Y., Artar, E., Ukav, İ. 2014. Adıyaman ilinde balıketi tüketim alışkanlıklarının belirlenmesi. Gıda Teknolojileri Elektronik Dergisi, 9(1): 21-25.

Özer, B. ve Akbay, C. 2014. Adana ili merkez ilçelerinde tüketicilerin dondurulmuş gıda tüketimi alışkanlıkları. XI. Ulusal Tarım Ekonomisi Kongresi, 3-5 Eylül, Samsun, s. 117-121.

Saygın, Ö., Demirbaş, N. 2017. Türkiye'de kırmızı et sektörünün mevcut durumu ve çözüm önerileri. Hayvansal Üretim, 58(1): 74-80.

Şahinli, M.A., Fidan, H. 2012. Estimation of food demand in Turkey: method of an almost ideal demand system. Qual Quant, 46: 653663.

Şeker, İ., Özen, A. 2011. Elazığ'da kırmızı et tüketim alışkanlıkları ve tüketicilerin hayvan refahı konusundaki görüşleri. Kafkas Üniv. Vet Fak Dergisi, 17(4): 543-550.

Şen, B., Canpolat, Ö., Sevim, A.F., Sönmez, F. 2008. Elazığ ilinde balık tüketimi. Fırat Üniversitesi Fen ve Mühendislik Bilimleri Dergisi, 20(3): 433-437.

Şenol, Ş., Saygı, H. 2001. Su ürünleri tüketiminin ekonometrik modeli. Ege Su Ürünleri Dergisi, 18(3): 383-390.

Tarım ve Orman Bakanlığı (TOB), Büyükbaş Hayvancilık Sayıları. https://www.tarimorman.gov.tr/HAYGEM/ Menu/6/Buyukbas-Hayvancilik (Erişim tarihi: 15.09.2018).

Türkiye Deniz Araştırmaları Vakfı (TÜDAV) 2017, Türkiye Denizleri Raporu. http://tudav.org/wp- 
content/uploads/2018/04/TUDAV_( Erişim tarihi: 10.02.2018).

Türkiye İstatistik Kurumu (TÜIK), Hane Gıda Harcamaları.

http://www.tuik.gov.tr/medas/?kn=132

(Erişim tarihi: 20.05.2016).

Türkiye İstatistik Kurumu (TÜIK), Tüketim Harcamaları istatistikleri. http://tuik.gov.tr/PreTablo.do?alt_id=1012 (Erişim tarihi: 10.09.2017).

Tekvar, S.O. 2016. Tüketici davranışlarının demografik özelliklere göre tanımlanması. Insan ve Toplum Bilimleri Araştırmaları Dergisi, 5(6): 1601-1616.

Terin, M., Bilgiç, A. 2017. Türkiye'de hanelerin tavuk eti tüketim harcamalarına etki eden faktörlerin ikili bağımlı Heckman örneklem seçicilik modeli ile analizi. 4. Uluslararası Beyaz Et Kongresi, 26-30 Nisan, Antalya, s. 20-27.

Terin, M., Hamamcı, G., Gül, T. 2016. Van ili kentsel alanda hanelerin balık tüketim yapısı ve satın alma davranışlarının belirlenmesi. Ege
Üniversitesi Su Ürünleri Dergisi, DOI: 10.12714/egejfas.2016.33.3.08: 242-249.

Turan, H., Kaya, Y., Sönmez, G. 2006. Balık etinin besin değeri ve insan sağlığındaki yeri. Ege Üniversitesi Su Ürünleri Dergisi, İzmir 23: 505-508.

Turan, H., Erkoyuncu, I., Kocatepe, D. 2013. Omega6 , omega-3 yağ asitleri ve balık. Yunus Araştırma Bülteni, (2):45-50.

Uzundumlu, A., Sezgin, A., Tekin, M.H. 2016. Balıketi tüketim eğilimini etkileyen faktörlerin analizi: Hakkari ili örneği. Alınteri, 31(B): 917.

Üstün, B., Tutal, O. 2008. Tüketim alışkanlıklarındaki değişimler alışveriş mekanlarına etkisinin Eskişehir örneğinde irdelenmesi. Anadolu Üniversitesi Sosyal Bilimler Dergisi, 8(2): 259282.

Yaylak, E., Taşkın, T., Koyubenbe, N., Konca, Y. 2010. İzmir İli Ödemiş ilçesinde kırmızı et tüketim davranışlarının belirlenmesi üzerine bir araştırma. Hayvansal Üretim. 51(1): 21-30. 